\title{
In vitro Assay of Alpha-Glucosidase Inhibitor Activities of Three Seagrasses from Banten Bay, Indonesia
}

\author{
Agung Widiyanto ${ }^{1}$, Effionora Anwar ${ }^{1 *}$, Tati Nurhayati ${ }^{2}$
}

\section{Agung Widiyanto ${ }^{1}$, Effionora Anwar ${ }^{1 *}$, Tati Nurhayati ${ }^{2}$}

'Faculty of Pharmacy, University of Indonesia, Depok 16424, INDONESIA. ${ }^{2}$ Department of Aquatic Products Technology, Bogor Agricultural University, Bogor 16680, INDONESIA.

Correspondence

\section{Mrs. Effionora Anwar}

Faculty of Pharmacy, University of Indonesia, JI.Prof.Dr. Mahar Marjono, Depok, West Java, INDONESIA, 16424

Phone no : +6221-7507254

E-mail: effionora.anwar@farmasi.ui.ac.id History

- Submission Date: 31-03-2018;

- Review completed: 16-05-2018;

- Accepted Date: 03-07-2018

DOI : 10.5530/pj.2018.5.152

Article Available online

http://www.phcogj.com/v10/i5

\section{Copyright}

(c) 2018 Phcog.Net. This is an openaccess article distributed under the terms of the Creative Commons Attribution 4.0 International license.

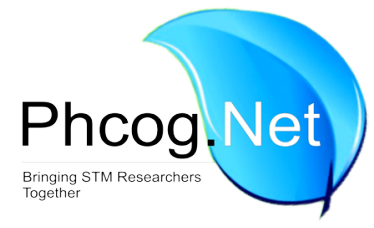

\begin{abstract}
Introduction: Diabetes mellitus (DM) is an endocrine disorder characterized by high blood glucose levels. One of the approaches for treating DM is by regulating the postprandial blood glucose via inhibition of $\alpha$-glucosidase enzymes. Seagrass is known as a plant containing bioactive compounds, especially for therapy antidiabetic. This research aims to evaluate the $\alpha$-glucosidase inhibition activity of three species seagrasses (Enhalus acoroides, Thalassia hemprichii and Cymodocea rotundata) from the Banten Bay, Indonesia. Methods: The extracts of all parts (root, leaf, and stem) from three seagrasses were prepared with maceration method using $80 \%$ ethanol solvents. The $\alpha$-glucosidase inhibitory activity was conducted by microplate reader at $400 \mathrm{~nm}$ using acarbose as a positive control. Furthermore, the kinetics of $\alpha$-glucosidase inhibition, phytochemical screening, and total phenolics content were evaluated against extract which has the most potential $\alpha$-glucosidase inhibition. Results: The result showed that the $80 \%$ ethanol extracts of Enhalus acoroides $\left(\mathrm{IC}_{50}\right.$ values $168.15 \pm 2.71$ $\mu \mathrm{g} / \mathrm{mL}$ ) had the most potential $\alpha$-glucosidase inhibitors activity compared with the positive control acarbose, Thalassia hemprichii and Cymodocea rotundata $\left(\mathrm{IC}_{50}\right.$ values $197.27 \pm 3.07$ $\mu \mathrm{g} / \mathrm{mL}, 425.86 \pm 5.15 \mu \mathrm{g} / \mathrm{mL}$ and $429.28 \pm 8.89 \mu \mathrm{g} / \mathrm{mL}$ ). The kinetic type of inhibition against $\alpha$-glucosidase was noncompetitive inhibition. The phytochemical compounds were phenols, flavonoid, terpenes, and tannin with the total phenolic content was $28.76 \pm 2.46 \mathrm{mgGAE} / \mathrm{g}$. Conclusion: Enhalus acoroides has the strongest inhibitor of $\alpha$-glucosidase and can be further developed for DM therapy agents.
\end{abstract}

Key words: Cymodocea rotundata, Diabetes mellitus, Enhalus acoroides, Phytochemical compound, Thalassia hemprichii.

\section{INTRODUCTION}

Handling of diabetes mellitus can be done through inhibition of the a-glucosidase enzyme that catalyzes the final step of starch digestion and abundant disaccharides in the human diet on the border of the small intestine mucosal brush. ${ }^{1-2}$ Seagrasses are marine angiosperms growing abundantly in the sea that produce secondary metabolites as an antidiabetic, ${ }^{3}$ antioxidant $^{3-4}$ and antibacterial ${ }^{5-6}$ activities with the chemical compound such as phenol, flavonoids, tannin, terpene, sterol. ${ }^{6-7}$ The aim of the present work is to investigate the a-glucosidase inhibitory activities of three seagrasses in Banten Bay, Indonesia i.e. Enhalus acoroides, Thalassia hemprichii and Cymodocea rotundata extracts.

\section{MATERIALS AND METHODS}

Materials

The plant parts used in this study were all plant parts (leaves, stems, and roots) collected in October 2017 from the Bay of Banten, Indonesia and identified by the Department of Biology, FMIPA University of Indonesia.
The chemical materials such as an $\alpha$-glucosidase enzyme which was obtained from Saccharomyces cerevisae (Sigma Aldrich, USA), $p$-nitrophenyl $\alpha$-Dglucopyranoside (pNPG) (Sigma Aldrich, USA), Acarbose (Huadong Medicine, China), Quercetin (Sigma Aldrich, German), bovine serum albumin (Merck, German). All reagents used in this research were analytical grade.

\section{Preparation of the extract}

All parts of the seagrass were washed with fresh water to remove epiphytes and other impurities. The sample was dried for 5 days in the shade at room temperature. The dried sample was homogenized to obtain the fine powder.

\section{Extraction}

Each dried powdered of seagrasses (100 g) were homogenized by Ultraturrax with a rotation speed $15.000 \mathrm{rpm}$ for $10 \mathrm{~min}$ and extracted by maceration for 2 days with $80 \%$ ethanol then evaporated.
Cite this article: Widiyanto A, Anwar E, Nurhayati T. In vitro Assay of Alpha-Glucosidase Inhibitor Activities of Three Seagrasses from Banten Bay, Indonesia. Pharmacog J. 2018;10(5):907-10. 


\section{The preliminary test of a-glucosidase}

The preliminary test performed was to determine the maximum wavelength of pNPG, optimum incubation time and substrate concentration using microplate reader.

\section{The a-glucosidase inhibition activity assay}

The a-glucosidase inhibition of the extracts was assayed according to the published method with modification. ${ }^{2}$ One $\mathrm{mg}$ of $\alpha$-glucosidase was dissolved in $10 \mathrm{~mL}$ of phosphate buffer ( $\mathrm{pH}$ 6.8) containing bovine serum albumin $(0.2 \% \mathrm{w} / \mathrm{v})$. Sample $(10 \mu \mathrm{L})$ was mixed with $66 \mu \mathrm{L}$ phosphate buffer ( $\mathrm{pH} 6.8$ ) and $17 \mu \mathrm{L}$ of $5 \mathrm{mM}$ pNPG then preincubated at $37^{\circ} \mathrm{C}$ for $5 \mathrm{~min} .7 \mu \mathrm{L}$ a-glucosidase $(0.07 \mathrm{unit} / \mathrm{mL})$ was added then incubated at $37^{\circ} \mathrm{C}$ for $15 \mathrm{~min}$.

Then $100 \mu \mathrm{L} \mathrm{Na}_{2} \mathrm{CO}_{3} 200 \mathrm{mM}$ was added to stop the reaction. The a-glucosidase activity was read at $400 \mathrm{~nm}$ in the microplate reader by measuring p-nitrophenol released from pNPG. As a positive control of the $\alpha$-glucosidase inhibitor used acarbose. An activity of $\alpha$-glucosidase standard and extract could be defined in \% inhibition which obtained using the following formula:

$$
\% \text { inhibition }=\frac{(\mathrm{A}-\mathrm{B})-(\mathrm{C}-\mathrm{D})}{\mathrm{A}-\mathrm{B}} \times 100
$$

$\mathrm{A}=$ blank solution absorption

$\mathrm{B}=$ blank control solution absorption

$\mathrm{C}=$ sample solution absorption

$\mathrm{D}=$ sample control solution absorption

The inhibitory concentrations of standard and extracts required to inhibit the action of $\alpha$-glucosidase by $50 \%\left(\mathrm{IC}_{50}\right)$ were calculated by linear regression.

\section{Type of inhibition a-glucosidase}

Inhibition types analysis were conducted only for the extract that has the best $\alpha$-glucosidase inhibition activity. This a nalysis measured a correlation between the concentration of pNPG as a substrate in the existence or absence of extract at different concentrations. The type of inhibition was described by the Lineweaver-Burk data plot analysis, which was calculated from the Michaelis-Menten kinetics results.

\section{Phytochemical screening}

The extract which has the best $\alpha$-glucosidase inhibition activity were evaluated for its bioactive compounds by Thin Layer Chromatography (TLC). The developed TLC plates were air dried and observed under ultraviolet light at $254 \mathrm{~nm}$ and $366 \mathrm{~nm}$. Then Retention factor (Rf) was calculated by dividing the distance of compound by the distance of solvent migration from the original position.

\section{Total phenolic content}

The total phenolic content of the extracts was measured by Folin-Ciocalteu method according to Vanitha et al. $(2017)^{7}$ with modification. An aliquot of the extract $(0.5 \mathrm{~mL})$ was mixed with $1 \mathrm{~mL}$ of Folin-Ciocalteu reagent $(10 \% \mathrm{v} / \mathrm{v})$. The tubes were vortexed for $20 \mathrm{sec}$ and allowed to stand for $5 \mathrm{~min}$. Two $\mathrm{mL}$ of sodium carbonate $(7.5 \% \mathrm{w} / \mathrm{v})$ was added. The tubes were vortexed again for $20 \mathrm{sec}$ and allowed to stand for $75 \mathrm{~min}$. Absorbance was then measured at $750 \mathrm{~nm}$ using the spectrophotometer UV-Vis. The total phenolic content was expressed as $\mathrm{mg} / \mathrm{g}$ Gallic acid equivalent.

\section{RESULTS}

\section{Extraction}

The percentages of each extract yield were shown below in Table 1.
Table 1: \% yield extract value.

\begin{tabular}{cccc} 
Sample & $\begin{array}{c}\text { Simplicial weight } \\
\text { extracted (gram) }\end{array}$ & $\begin{array}{c}\text { Crude extract } \\
\text { weight (gram) }\end{array}$ & Yield (\%) \\
\hline E. acoroides & 100 & 6.48 & 6.48 \\
T. hemprichii & 100 & 7.12 & 7.12 \\
C. rotundata & 100 & 7.09 & 7.09 \\
\hline
\end{tabular}

\section{The preliminary test of a-glucoside activity}

The determination of maximum wavelength, incubation time and also substrate optimization was performed in enzyme solutions $0.07 \mathrm{U} / \mathrm{mL}$. Temperature and $\mathrm{pH}$ used in the product information from Sigma Aldrich was $37^{\circ} \mathrm{C}$ and $\mathrm{pH}$ 6.8. Then the substrate concentration was optimized to determine the appropriate substrate concentration to react with enzyme unit used. Substrate concentration was said optimum if all active site in the enzyme had been bound to the substrate so that there were no free enzyme which would produce products. In substrate optimization, enzyme unit was used $0.07 \mathrm{U} / \mathrm{mL}$ with substrate variations were 1,$25 ; 2,5 ; 5 ; 10 ; 15 ; 20$; and $30 \mathrm{mM}$. The result showed that the optimum concentration of pNPG was $5 \mathrm{mM}$. The optimum conditions for the enzyme were $400 \mathrm{~nm}, 15 \mathrm{~min}$ incubation time and $5 \mathrm{mM}$ substrate concentration.

\section{a-glucosidase inhibition activity assay}

Inhibition $\alpha$-glucosidase activity of extracts was determined using pNPG as a substrate and compared with acarbose (Figure 1). The $\mathrm{IC}_{50}$ values of the three types of seagrass extract and acarbose as controls have been obtained. The sequence inhibition $\alpha$-glucosidase activity from the strong potential to the weak is the extracts of Enhalus acoroides $(168.15 \pm 2.71$ $\mu \mathrm{g} / \mathrm{mL})$, acarbose $(197.27 \pm 3.07 \mu \mathrm{g} / \mathrm{mL})$, Thalassia hemprichii $(425.86 \pm$ $5.15 \mu \mathrm{g} / \mathrm{mL})$ and Cymodocea rotundata $(429.28 \pm 8.89 \mu \mathrm{g} / \mathrm{mL})$. The type of inhibition of $80 \%$ ethanol extract of Enhalus acoroides was investigated and showed a noncompetitive inhibition (Figure 2).

\section{Phytochemical screening}

The $80 \%$ ethanol extract from Enhalus acoroides was identified with TLC showing the presence of phenol, flavonoid, terpene and tannin compounds (Table 2). ${ }^{9}$

\section{Total phenolic content}

The total phenols were expressed as $\mu \mathrm{g} / \mathrm{mL}$ gallic acid equivalent. Standard curve equation was used: $y=0,00037 x+0,135, R 2=0,995$, where $y$ is the absorbance value at $750 \mathrm{~nm}$. The total phenolic content of the $80 \%$ ethanol extract Enhalus acoroides was $28.76 \pm 2.46 \mathrm{mgGAE} / \mathrm{g}$.

\section{DISCUSSION}

The $80 \%$ ethanol extract Enhalus acoroides had the highest $\alpha$-glucosidase inhibition activity compare with Thalassia hemprichii and Cymodocea rotundata and more potential than acarbose. The a-glucosidase inhibition activity of the three types of seagrass extracts is more likely due to more than one compounds containing in the extracts such as phenolic and terpenoid compounds in each extract. Their chemical compounds may have a synergic effect to inhibit the enzyme a-glucosidase. ${ }^{8}$ The type of enzyme inhibition mechanism of $80 \%$ ethanol extract Enhalus acoroides was a noncompetitive inhibitor. Noncompetitive inhibition may have been due to the chemical compound extract as an inhibitor binds to the enzyme at a location other than the active site. ${ }^{2}$ The phytochemical compound of the extract is phenols, flavonoid, tannin and terpene. While the total phenolic content of the $80 \%$ ethanol extract Enhalus acoroides was $28.76 \pm 2.46 \mathrm{mgGAE} / \mathrm{g}$. Phenolics compounds are reported as antioxidant, anti-inflammatory, antidiabetic etc. ${ }^{3,5,10}$ Phenolic compounds 


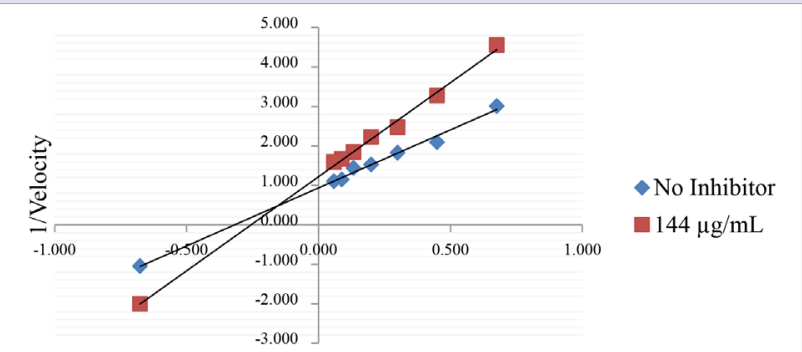

$1 /$ Substrat concentration

Figure 2: Lineweaver-Burk plot of $80 \%$ ethanol extract of Enhalus acoroides with concentration of $144 \mu \mathrm{g} / \mathrm{mL}$.

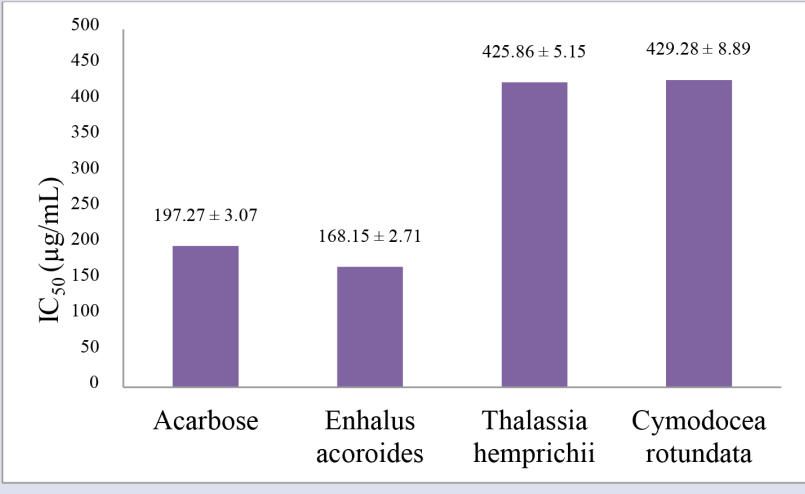

Figure 1: $I C_{50}$ value standard and extract against a-glucosidase.

Table 2: Phytochemical Analysis of $\mathbf{8 0} \%$ ethanol extract from Enhalus acoroides by Thin Layer Chromatography.

\begin{tabular}{|c|c|c|c|c|c|c|c|c|}
\hline $\begin{array}{l}\text { Chemical } \\
\text { name }\end{array}$ & Solvent system & Rf values & $\begin{array}{l}\text { Detection/ } \\
\text { Spray reagent }\end{array}$ & $\begin{array}{c}\text { Color of day } \\
\text { light }\end{array}$ & UV 254 & UV 366 & $\begin{array}{l}\text { Colour with } \\
\text { spray reagent }\end{array}$ & Summary \\
\hline Phenol & cloroform: methanol (9:1) & $0.25 ; 0.38$ & $\mathrm{FeCl}_{3}$ & yellow & black & black & black & + \\
\hline Terpene & n-hexane: etil acetat (1:1) & 0.31 & $\begin{array}{c}\text { Vanilin-sulfic } \\
\text { acid }\end{array}$ & yellow & black & dark blue & purple & + \\
\hline Tannin & methanol: aquadest (6:4) & $0.19 ; 0.69$ & $\mathrm{FeCl}_{3}$ & yellow & dark blue & black & black & + \\
\hline Flavonoid & n-butanol:acetid acid: aquadest ( $4: 1: 5)$ & 0.87 & $\begin{array}{l}\text { Quercetin } \\
\text { standard }\end{array}$ & yellow & brown & purple & (no spray) & + \\
\hline
\end{tabular}

$(+)$ : present.

affect responses that are related to diabetes by inhibiting a-glucosidase enzyme thereby decreasing starch digestion. ${ }^{11-13}$

\section{CONCLUSION}

The 80\% ethanol extract Enhalus acoroides $\left(\mathrm{IC}_{50}\right.$ values :168.15 \pm 2.71 $\mu \mathrm{g} / \mathrm{mL}$ ) had the highest $\alpha$-glucosidase inhibition activity compare with Thalassia hemprichii, and Cymodocea rotundata $\left(\mathrm{IC}_{50}\right.$ values : $425.86 \pm$ $5.15 \mu \mathrm{g} / \mathrm{mL} ; 429.28 \pm 8.89 \mu \mathrm{g} / \mathrm{mL}$ ) and more potential than acarbose $\left(\mathrm{IC}_{50}\right.$ values : $\left.197.27 \pm 3.07 \mu \mathrm{g} / \mathrm{mL}\right)$. While the type of enzyme inhibition mechanism of $80 \%$ ethanol extract Enhalus acoroides was a noncompetitive inhibitor. The phytochemical compound of the extract is phenols, flavonoid, tannin and terpene. The total phenolic content of the $80 \%$ ethanol extract Enhalus acoroides was $28.76 \pm 2.46 \mathrm{mgGAE} / \mathrm{g}$. Enhalus acoroides potential inhibits the $\alpha$-glucosidase enzyme and further research about the isolation of active compounds is possible.

\section{ACKNOWLEDGEMENT}

The author is grateful to National Agency Drug and Food Control Indonesia, Ministry RISTEK-DIKTI of Indonesia for funding the research and also thankful to the authorities of the Faculty of Pharmacy, University of Indonesia for supporting equipment and facilities.

\section{CONFLICT OF INTEREST}

Nil (The author declares no conflict of interest.

\section{ABBREVIATIONS}

DM: Diabetes Mellitus; a-glucosidase: Alpha-glucosidase; IC $_{50}$ : Half Maximal Inhibitory Activity; TLC: Thin Layer Chromatography; pNPG: p-Nitrophenyla-D-glucopyranoside; GAE: Gallic Acid Equivalent.

\section{REFERENCES}

1. Kim KY, Nam KA, Kurihara H, Kim SM. Potent alpha-glucosidase inhibitors purified from the red alga Grateloupia elliptica. Phytochemistry. 2008;69(16):2820-5.

2. Kazeem MI, Adamson JO, Ogunwande IA. Modes of inhibition of $\alpha$-amylase and $\alpha$-glucosidase by aqueous extract of Morinda lucida benth leaf. BioMed Research International. 2013;527-70.

3. Gökçe G, Haznedaroglu MZ. Evaluation of antidiabetic, antioxidant and vasoprotective effects of Posidonia oceanica extract. Journal of Ethnopharmacology. 2008;115(1):122-30.

4. Senthilkumar $P$, Vanthana M, Sandhiya AM, Ranjith SK, Hajistha HP, Sarathkumar $\mathrm{S}$, et al. Seagrass-mediated silver nanoparticles synthesis by Enhalus acoroides and its $\alpha$-glucosidase inhibitory activity from the Gulf of Mannar. J Nanostruct Chem. 2016;6(3):275-80.

5. Qi SH, Zhang S, Qian PY, Wang BG. Antifeedant, antibacterial and antilarval compounds from the South China Seagrass Enhalus acoroides. Bot Mar. 2008;51(5):441-7.

6. Kannan RR, Amurugam R, Anantharaman P. Antibacterial potential of three seagrass againts human pathogens, Asian Pasific Journal of Tropical Medicine. 2010;3(11):890-3.

7. Amudha $P$, Vanitha $V$, Bharathi PN, Jayalakshmi M, Mohanasundaram S. Phytochemical analysis and in vitro antioxidant screening of sea grass-Enhalus acoroides. Int J Res Pharm Sci. 2017;8(2):251-8.

8. Elya B, Basah K, Mun'im A, Yuliastuti W, Bangun A, Septiana EK. Screening of $\alpha$-glucosidase inhibitory activity from some plants of Apocynaceae, Clusiaceae, Euphorbiaceae, and Rubiaceae. J Biomed Biotechnology. 2012.

9. Kannan RR, Arumugam R, Meenakhshi S, Anantharaman P. Thin layer chromatography analysis of antioxidant constituents from seagrasses of Gulf of 
Mannar. Biosphere Reserve,South India. Int J ChemTech Res. 2010;2(3):1526-30.

10. Santoso J. Phenol content, Antioxidant activity and fibers profile of four tropical seagrasses from indonesia. Journal of Coastal Development. 2012;15(2):18996.

11. Lin D, Xiao M, Zhao J, Li Z, Xing B, Li X, et al. An overview of plant phenolic compounds and their importance in human nutrition and management of type
2 diabetes. Molecules. 2016;21(10):1974.

12. Xiao JB, Hogger P. Dietary polyphenols and type 2 diabetes: Current insights and future perspectives. Curr Med Chem. 2014;22(1):23-38.

13. Ashiq $U$, Ara R, Saleem M. Alpha-glucosidase and carbonic anhydrase inhibition studies of Pd (II)-hydrazide complexes. Arab J Chem. King Saud University. 2017;10(4):488-99

\section{SUMMARY}

- Alpha-glucosidase inhibition activity of $80 \%$ ethanol extract of three seagrasses were determined.

- The $80 \%$ ethanol extract of Enhalus acoroides has the best $\alpha$-glucosidase inhibition activity.

- $\quad \mathrm{IC}_{50}$ value extract of Enhalus acoroides : $168.15 \pm 2.71 \mu \mathrm{g} / \mathrm{mL}$, Thalassia hemprichii: $425.86 \pm 5.15 \mu \mathrm{g} / \mathrm{mL}$ and Cymodocea rotundata: $429.28 \pm 8.89 \mu \mathrm{g} / \mathrm{mL}$.

- Inhibition types analysis, Phytocemical compounds, and total phenolic content were conducted only for Enhalus acoroides.

- The type of enzyme inhibition mechanism of $80 \%$ ethanol extract Enhalus acoroides was a noncompetitive inhibitor.

- $\quad$ Phytocemical compounds of $80 \%$ ethanol extract Enhalus acoroides i.e. phenols, flavonoid, tannin, and terpene were analyzed using Thin Layer Chromatography.

- The total phenolic content of the $80 \%$ ethanol extract Enhalus acoroides was $28.76 \pm 2.46 \mathrm{mgGAE} / \mathrm{g}$.

Cite this article: Widiyanto A, Anwar E, Nurhayati T. In vitro Assay of Alpha-Glucosidase Inhibitor Activities of Three Seagrasses from Banten Bay, Indonesia. Pharmacog J. 2018;10(5):907-10. 